\title{
Проблемні статті
}

$616.12-008.331 .1$

\author{
T.М. Бойчук, В.К. Тащук
}

\section{АРТЕРІАЛЬНА ГІПЕРТЕНЗІЯ - ПРОБЛЕМА СЬОГОДЕННЯ}

Буковинський державний медичний університет, м. Чернівці

Резюме. Проблема лікування артеріальної гіпертензії, 3 огляду на очікувану кількість у 2025 р. в 1,5 млрд осіб $з$ підвищенням артеріального тиску, демонструє необхідність впровадження як сучасних методів діагностики, так і найефективніших підходів до лікування,

У 1711 p. англійський священик Стівен Гейлс проводить зондування серця коня, застосувавши як катетер латунну трубку в стегнову артерію тварини та з'єднавши з вертикально встановленою скляною трубкою - після зняття затиску 3 артерії кров у трубці піднялася на висоту 250 см і iii рівень став коливатися синхронно зі скороченням серця. Описи гіпертонії, як хвороби, надані Томасом Юнгом у 1808 р. і Річардом Брайтом у 1836 р., а першу доповідь про підвищений артеріальний тиск (АТ) у людини без ознак захворювання нирок зробив Фредерік Акбар Магомед (1849-1884 рр.). Взагалі артеріальна гіпертензія (АГ), як нозологічна одиниця, реалізована після винаходу стетоскопа Рене Лаеннеком (1816 р.) та сфігмоманометра на основі манжети Сципіоном Ріва-Роччі (1896 р.), а в 1905 р. Микола Коротков удосконалив техніку, описавши «звуки Короткова», які звучали, коли артерії вислуховуються за допомогою стетоскопа в той час, як манжета сфігмоманометра зменшує тиск [10].

Сьогодні у світі, за даними ВОО3, не знають про АГ 56,7\%, знають про АГ, але не лікують, ще $28,8 \%$, лікують АГ, але не контрольовано, $14,5 \%$; контроль АГ на рівні менше 140/90 мм рт.ст. не досягається у $69 \%$ пацієнтів, а підвищений АТ реєструється в США у 76.400.000 мешканців (33,5 \% старших 20 років) [9], у світі у 2000 р. налічували 972 млн хворих на АГ, зараз 1 млрд, у 2025 р. - їх очікується 1,5 млрд. Згідно 3 виступами міністра охорони здоров'я України, члена-кореспондента НАМН України Р.В. Богатирьової та директора ННЦ «Інститут кардіології iм. акад. М.Д. Стражеска», академіка НАМН В.М. Коваленка в Україні поширеність провідних хвороб системи кровообігу серед дорослих в аналогічний період свідчить про подібний розподіл (табл. 1) [1-3].

Аналіз стандартизованих за віком показників поширеності АГ, обізнаності про наявність $\mathrm{AГ}$, охоплення медикаментозним лікуванням та його ефективність, продовжують потребувати невпинної уваги лікарів (табл. 2) [1-3].

А отже, питання первинної і вторинної профілактики АГ повинні посідати чільне місце в чому і присвячене впровадження на засадах принципів «комплаєнса» $\mathrm{i}$ «едгіренса» механізмів реімбурсації.

Ключові слова: артеріальна гіпертензія, артеріальний тиск, лікування, реімбурсація.

науково-лікувальному напрямку сучасного спрямування розвитку кардіологічної складової діяльності лікаря і науковця як стосовно модифікованих (підвищений АТ, куріння, дисліпідемія, цукровий діабет, ожиріння, дієтичні чинники, тромбогенні чинники, недостатня фізична активність, надмірне вживання алкоголю), так і немодифікованих (наявність ішемічної хвороби серця, обтяжена спадковість, вік, стать) факторів ризику. За даними ВОО3, третина смертей серед 10 ризикфакторів (недовиношеність, небезпечний секс, підвищений АТ, тютюн, алкоголь, ненадійна вода, очищення і гігієна, високий холестерин, дим від твердих палив, залізодефіцит), якраз і корелює з факторами ризику для АГ.

В останніх рекомендаціях і настановах $[5,6$, 7] зазначено, що серед показників, які використовуються для оцінки сумарного ризику ускладнень АГ, домінуючими є: вік (у чоловіків $>55$ р., у жінок $>65$ р.), високий пульсовий тиск у осіб літнього віку ( $\geq 60$ мм рт.ст.), куріння, дисліпідемія (загальний холестерин (3ХС) $>5,0$ ммоль/л або ХС ліпопротеїнів низької щільності (ЛПНЩ) $>3,0$ ммоль/л, або ХС ЛП високої щільності (ЛПВЩ) $<1,0$ ммоль/л у чоловіків і $<1,2$ ммоль/л у жінок, або тригліцеридів (ТГ) >1,7 ммоль/л), глюкоза плазми натще 5,6-6,9 ммоль/л, порушення толерантності до глюкози, абдомінальне ожиріння (окружність талії $>102$ см у чоловіків і $>88$ см у жінок), серцево-судинні захворювання в сімейному анамнезі (до 55 років у чоловіків, до 65 років у жінок).

$€$ декілька питань, що формують наш сьогоднішній світогляд щодо АГ.

1. Що ми визначаємо як AT? Тільки маркер для більшої проблеми!

2. Чи є правдою визначення АГ як складної нозології? АГ - мультиорганне, системне захворювання!

3. Чи с проблемою діагностика і лікування $\boldsymbol{A \Gamma} ?$ ? Асимптомність АГ спостерігається у $85 \%$ випадків!

Відоме правило «половини» - на кожні 800 осіб у суспільстві: 
1) у 400 АГ (підвищений систолічний АТ (САТ) або діастолічний АТ (ДАТ), або підвищення САТ і ДАТ);

2) 3 них у 200 - діагностують АГ;

3) з них у 100 - розпочнуть лікування;

4) 3 них у 50 - адекватне лікування;

5) 3 них у 25 - досягнуть цільового АТ, а отже, всього 25 із 400 (тобто $6 \%$ ) досягнуть цільовий АТ, що в тому числі реалізується через довіру до призначень лікаря, оскільки терміни «комплаєнс»/«едгіренс»/«конкорданс» (англ. compliance/adherence/concordance - згода/ прихильність/відповідність) у сьогоденній терапії АГ є широко вживаними з огляду на готовність, здатність, бажання й обов'язок пацієнта виконувати призначення лікаря, а термін «едгіренс» - як прихильність або більший ступінь відповідальності пацієнта щодо рекомендованої поведінки (дієта, модифікація способу життя, медикаментозна тактика) та втягнення хворих у систему медичної турботи про власний стан здоров'я є заакцептованим, визначається позитивним ставленням до лікаря, довірою до системи медичної допомоги, ознайомленням з рекомендаціями з лікування АГ, a їх імплементація зумовлює ефективність лікування.

Отже, діагностика АГ і реалізація Наказу MO3 України №384 потребують оптимізації діаг- ностики і раннього виявлення АГ, у тому числі за активного впровадження показників, які використовуються для оцінки сумарного ризику ускладнень (вивлення ознак гіпертрофії лівого шлуночка (ГЛШ) згідно з ЕКГ-критеріями СоколоваЛайона $>38$ мм та Корнельським вольтажним індексом >2440 мм/мс і ехокардіографічними критеріями - індексу маси міокарда ЛШ для чо-

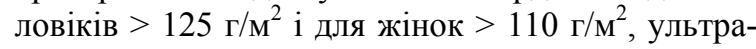
звукових ознак потовщення стінок судин (товщина інтими-медії сонної артерії >0,9 мм) або наявності атеросклеротичної бляшки; швидкості пульсової хвилі $12 \mathrm{~m} / \mathrm{c}$; індексу АТ гомілка/ плечова артерія < 0,9; підвищення концентрації креатиніну (у чоловіків 115-133 мкмоль/л, у жінок - 107-124 мкмоль/л); зниження розрахункового показника швидкості клубочкової фільтрації; мікроальбумінурія (30-300 мг/добу).

Найбільш придатними і простими у використанні для практичного лікаря є оцінка індексу АТ гомілка/плечова артерія, який складається 3 наступної процедури:

1) одночасне вимірювання АТ на обох руках у положенні сидячи (тричі з обчисленням середньої величини). При цьому визначити руку, на якій АТ вищий;

2) одночасне вимірювання АТ на руці з більшим рівнем АТ та на нозі в положенні лежачи

Таблиця 1

Поширеність провідних хвороб системи кровообігу серед дорослих в Україні (2010)

\begin{tabular}{|c|c|c|}
\hline \multirow{2}{*}{ Хвороби } & \multicolumn{2}{|c|}{ Поширеність } \\
\cline { 2 - 3 } & Абсолютна кількість & На 100 000 населення \\
\hline Хвороби системи кровообігу & 25896126 & 68687,3 \\
\hline Гіпертонічна хвороба & 12122512 & 32154,0 \\
\hline Ішемічна хвороба серця & 8843165 & 23455,8 \\
\hline Гострий інфаркт міокарда & 50004 & 832,6 \\
\hline Цереброваскулярні хвороби & 3198061 & 282,3 \\
\hline Інсульт & 106427 & 286 \\
\hline
\end{tabular}

Таблиця 2

\begin{abstract}
Стандартизовані за віком показники поширеності артеріальної гіпертензії, обізнаності про наявність артеріальної гіпертензії, охоплення медикаментозним лікуванням та його ефективність серед дорослих в Україні
\end{abstract}

\begin{tabular}{|c|c|c|c|c|c|c|}
\hline \multirow{2}{*}{\begin{tabular}{c} 
Показники \\
\cline { 2 - 7 }
\end{tabular}} & \multicolumn{3}{|c|}{ Міська популяція } & \multicolumn{3}{c|}{ Сільська популяція } \\
\cline { 2 - 7 } & чол. & жін. & $\begin{array}{c}\text { обидві } \\
\text { статі }\end{array}$ & чол. & \multicolumn{2}{|c|}{$\begin{array}{c}\text { жін. } \\
\text { обидві } \\
\text { статі }\end{array}$} \\
\hline Поширеність АГ & 30 & 29 & 30 & 38 & 35 & 36 \\
\hline Обізнаність про наявність АГ & 60 & 68 & 63 & 56 & 87 & 38 \\
\hline $\begin{array}{c}\text { Охоплення медикаментозним ліку- } \\
\text { ванням }\end{array}$ & 27 & 54 & 38 & 23 & 56 & 8 \\
\hline Ефективність лікування & 10 & 25 & 14 & 3 & 15 & 8 \\
\hline
\end{tabular}


(тричі з обчисленням середньої величини на одній, а потім тричі на іншій нозі);

3) обчислення гомілково-плечового індексу як співвідношення середнього рівня САТ окремо на правій та лівій гомілці до середнього рівня САТ на плечі руки з вищим АТ;

4) при його величині менше 0,9 - стенотичне ураження артерій на відповідному боці.

Необхідно позиціонування пацієнта на правильності вимірювання АТ. Згідно з рекомендаціями Європейського товариства гіпертензії та Європейського товариства кардіології (2007) [7] проведення вимірювання АТ складається з наступних заходів:

1) визначається у спокійній обстановці після 5 хв відпочинку;

2) за 30 хв до вимірювання не курити чи не пити кави;

3) манжета повинна охоплювати не $<80 \%$ окружності плеча і покривати $2 / 3$ його довжини (вузька/коротка манжета - завищує АТ, широка занижує АТ). Стандартна манжета дорівнює 1213 см у ширину та 35 см у довжину;

4) нижній край манжети накладається на 22,5 см вище ліктьової ямки, між манжетою і поверхнею плеча - проходить палець;

5) доцільно визначити САТ пальпаторним методом (оцінити пульс на a.radialis, швидко на- качати повітря в манжету до 70 мм рт.ст., далі по 10 мм рт.ст. до значення, при якому зникає пульсація - показник відновлення пульсу дорівнює САТ, що допомогає уникнути помилки, пов'язаної 3 «аускультативним провалом» (зникненням тонів Короткова відразу після їх першої появи), далі повторно повітря накачують на 20-30 мм рт.ст. вище значень САТ, які були визначені пальпаторно;

6) далі випускати повітря повільно (2 мм pт.ст./c) 3 визначенням I фази тонів Короткова (появу - тобто САТ) і V фази (зникнення - ДАТ), АТ округлюють до найближчих 2 мм рт.ст., вимірювання проводиться не менше двох разів 3 інтервалом 2-3 хв, при розходженні результатів $>5$ мм рт.ст. - виконується повторно через декілька хв, АТ контролюється на обох руках, у положенні сидячи, стоячи і лежачи, до уваги беруть більш високі значення.

Якості критерій ГЛШ при скринінговому дослідженні є придатним контроль ЕКГ-критеріїв Соколова-Лайона та Корнельського вольтажного індексу. Рекомендованим є визначення індексу Соколова-Лайона, як суми $\mathrm{S}_{\mathrm{V} 1}+\mathrm{R}_{\mathrm{V} 5}$ або v6 $>38$ мм, та модифікованого Корнельского вольтажного індексу для жінок [RaVL (мм) + SV3 (мм) + 6] x QRS (мс) та чоловіків [RaVL (мм) + SV3 (мм)] х

\begin{tabular}{|c|c|c|c|c|c|}
\hline & \multicolumn{5}{|c|}{ Рівень АТ, мм рт. ст. } \\
\hline $\begin{array}{l}\text { Фактори } \\
\text { стратифікації }\end{array}$ & $\begin{array}{l}\text { Нормальний } \\
\text { САТ 120-129 } \\
\text { ДАТ 80-84 }\end{array}$ & $\begin{array}{l}\text { Вис. норм. } \\
\text { САТ 130-139 } \\
\text { ДАТ } 85-89\end{array}$ & $\begin{array}{l}\text { АГ 1-го } \\
\text { ступеня } \\
\text { САТ 140-159 } \\
\text { ДАТ } 90-99\end{array}$ & $\begin{array}{l}\text { АГ 2-го } \\
\text { ступеня } \\
\text { САТ 160-179 } \\
\text { ДАТ 100-109 }\end{array}$ & $\begin{array}{l}\text { АГ 3-го } \\
\text { ступеня } \\
\text { САТ> } 180 \\
\text { ДАТ> } 110\end{array}$ \\
\hline $\begin{array}{l}\text { Немає факторів } \\
\text { ризику }\end{array}$ & \multicolumn{2}{|c|}{$\begin{array}{c}\text { Середній ризик в } \\
\text { популяції }\end{array}$} & $\begin{array}{c}\text { Додатковий } \\
\text { низький }\end{array}$ & $\begin{array}{c}\text { Додатковий } \\
\text { помірний }\end{array}$ & $\begin{array}{c}\text { Додатковий } \\
\text { високий }\end{array}$ \\
\hline $\begin{array}{l}\text { 1-2 фактори } \\
\text { ризику }\end{array}$ & $\begin{array}{c}\text { Додатковий } \\
\text { низький }\end{array}$ & $\begin{array}{c}\text { Додатковий } \\
\text { низький }\end{array}$ & $\begin{array}{c}\text { Додатковий } \\
\text { помірний }\end{array}$ & $\begin{array}{c}\text { Додатковий } \\
\text { помірний }\end{array}$ & $\begin{array}{c}\text { Додатковий } \\
\text { дуже } \\
\text { високий }\end{array}$ \\
\hline $\begin{array}{l}\text { Множинні } \\
\text { фактори ризику, } \\
\text { ураж. } \\
\text { органів-мішеней, } \\
\text { МС, цд }\end{array}$ & $\begin{array}{c}\text { Додатковий } \\
\text { помірний }\end{array}$ & $\begin{array}{c}\text { Додатковий } \\
\text { високий }\end{array}$ & $\begin{array}{c}\text { Додатковий } \\
\text { високий }\end{array}$ & $\begin{array}{c}\text { Додатковий } \\
\text { високий }\end{array}$ & $\begin{array}{c}\text { Додатковий } \\
\text { дуже } \\
\text { високий }\end{array}$ \\
\hline $\begin{array}{l}\text { Серцево-судинні } \\
\text { захворювання }\end{array}$ & $\begin{array}{c}\text { Додатковий } \\
\text { дуже } \\
\text { високий }\end{array}$ & $\begin{array}{c}\text { Додатковий } \\
\text { дуже } \\
\text { високий }\end{array}$ & $\begin{array}{c}\text { Додатковий } \\
\text { дуже } \\
\text { високий }\end{array}$ & $\begin{array}{c}\text { Додатковий } \\
\text { дуже } \\
\text { високий }\end{array}$ & $\begin{array}{c}\text { Додатковий } \\
\text { дуже } \\
\text { високий }\end{array}$ \\
\hline
\end{tabular}

Рис. 1. Стратифікація ризику для оцінки прогнозу у хворих з АГ

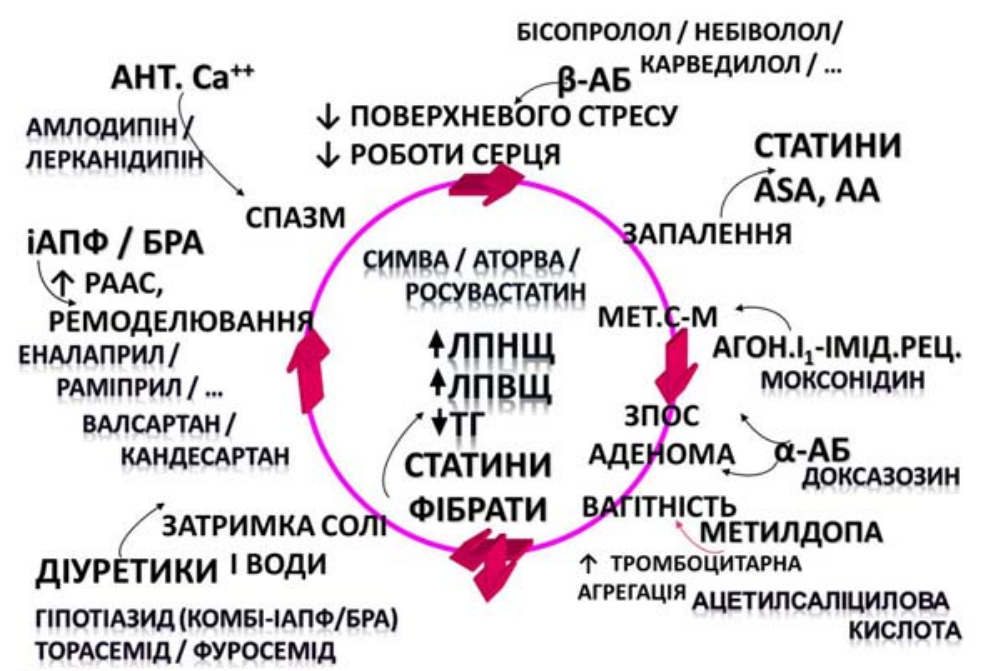

Рис. 2. Патогенетично обгрунтована терапія АГ 


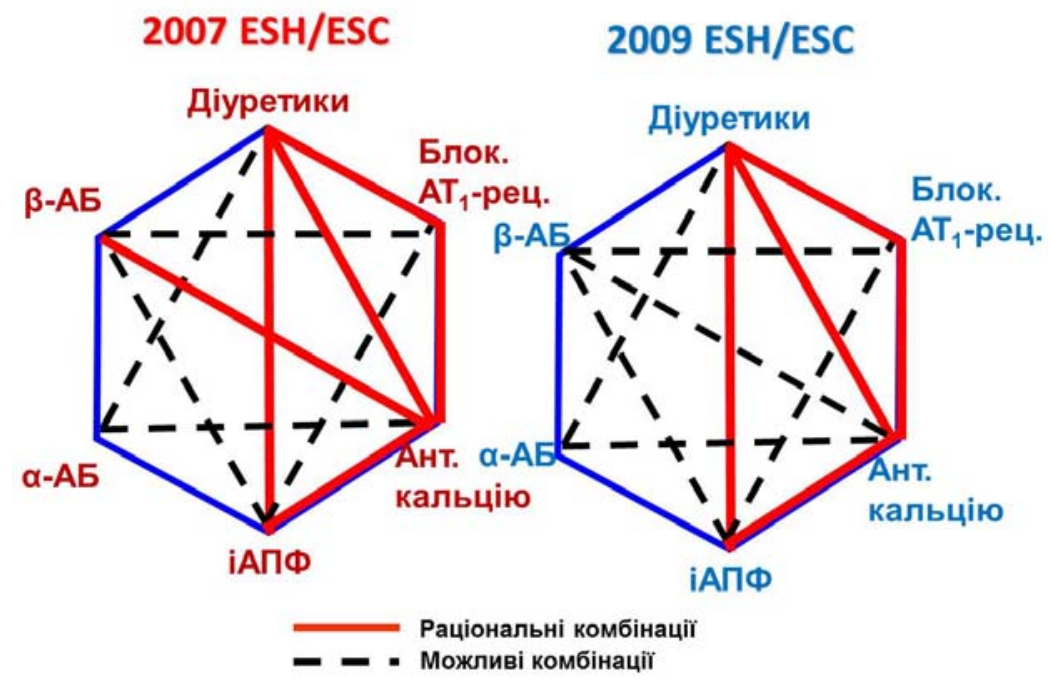

Рис. 3. Раціональні комбінації лікування артеріальної гіпертензії

\begin{tabular}{|c|c|c|}
\hline $\begin{array}{c}\text { Анатомо-терапевтично- } \\
\text { хімічний код }\end{array}$ & $\begin{array}{c}\text { Міжнародна непатентована } \\
\text { назва українською мовою }\end{array}$ & $\begin{array}{c}\text { Міжнародна непатентована } \\
\text { назва англійською мовою }\end{array}$ \\
\hline \multicolumn{3}{|c|}{ Засоби, що діють на ренін-ангіотензинову систему } \\
\hline С09АА02 & Еналаприл & Enalapril \\
\hline С09АА03 & Лізиноприл & Lisinopril \\
\hline \multicolumn{3}{|c|}{ Блокатори бета-адренорецепторів } \\
\hline С07АВ07 & Бісопролол & Bisoprolol \\
\hline С07АВ02 & Метопролол & Nebivolol \\
\hline С07АВ12 & Небіволол & Amlodipine \\
\hline \multicolumn{3}{|c|}{ Антагоністи кальцію } \\
\hline С08СА01 & Амлодипін & Nifedipine \\
\hline С08СА05 & Ніфедипін & \\
\hline
\end{tabular}

Рис. 4. Препарати для лікування артеріальної гіпертензії в системі реімбурсації

QRS (мс), ГЛШ визначається при показниках індексу, що більші $2440 \mathrm{mм} \cdot \mathrm{mc}(>2440 \mathrm{mV} \cdot \mathrm{ms})$.

Одним із показників, використання яких $\epsilon$ доцільним, визначено оцінку зниження розрахункового показника швидкості клубочкової фільтрації (за формулою MDRD) (<60 мл/хв/1,73м²) або розрахункового кліренсу креатиніну (за формулою Кокрофта-Гаулта) (<60 мл/хв), що представлено формулами:

1) обчислення швидкості клубочкової фільтрації (ШКФ) за формулою Кокрофта-Гаулта: $[140$ - вік (роки) $] \times$ МТ(кг) $] \times 0,85$ (для жінок) ШКФ (мл/хв) = - Креатинін (мкмоль/л)×0,81

2) обчислення швидкості клубочкової фільтрації (ШКФ) креатиніну (Кр) плазми за формулою MDRD: 0,203 ,

$$
\text { еШКФ }=186 \times(\mathrm{Kp} \times 0,0113)-1,154 \times \text { Вiк - }
$$

еШКФ $=0,742 \times 186 \times(\mathrm{Kp} \times 0,0113)-1,154 \times$ Вік -0,203 (для жінок).
Використання контролюючих методів дозволяє врешті-решт прогнозувати ризик АГ, а отже вплинути на його перебіг (рис. 1).

Коли починати лікування АГ? Згідно з рекомендаціями Європейського товариства гіпертензії та Європейського товариства кардіології (2007) відразу - при АТ $\geq 180 / 110$ мм рт.ст., за ураження органів-мішеней або супутніх захворювань! Слід призначати лікування - при повторних вимірюваннях $\mathrm{AT} \geq 160 / 100$ мм рт.ст.; за рівня АТ 140/90155/99 мм рт.ст. - медикаменти при високому ризику ускладнень та при АТ $\geq 140 / 90$ мм рт.ст. 3 низьким або помірним ризиком ускладнень за одноготрьох міс. спостереження і підвищеним АТ $\geq 140 / 90$ мм рт.ст. Отже, ризик АГ є одним з основних чинників впливу лікаря на необхідність стабілізації ситуації, а завдяки впровадженню останніх рекомендацій він $є$ чітко визначеним (рис. 1).

Еволюція лікування АГ чітко прослідковується в рекомендаціях Joint National Committee on Prevention, Detection, Evaluation, and Treatment of High Blood Pressure (JNC, CШA). 
Так згідно з JNC-I (1977) і JNC-II (1980) у лікуванні АГ запропонований ступінчастий підхід, препаратами 1-го вибору стали тіазидові діуретики, а за їх недостатньої ефективності, послідовно призначали резерпін, гідралазин, клонідин, метилдопа, пропранолол, гангліоблокатори. Розвиток уявлень про АГ змінювали JNC-III (1984), а отже, класом засобів першого вибору визначили $\beta$-адреноблокатори ( $\beta$-АБ), антигіпертензивна терапія стає менш структурованою, тактика лікування - індивідуалізованою. За впровадження JNC-IV (1988) - препаратами вибору в лікуванні АГ визнані антагоністи кальцію та інгібітори ангіотензинперетворювального ферменту (іАПФ), пропонується немедикаментозне зниження АТ - у цей період доведено ефективність дієти - згідно 3 дослідженням DASH $[8,11]$ використання низькосольової дієти з фруктами, овочами та продуктами 3 низьким вмістом жирів дозволяє знизити АТ на 11,4/5,5 мм рт.ст., зменшення маси тіла - втратити 5-20 мм рт.ст. на кожні 10 кг, використання гіпонатрієвої дієти - ще 2-8 мм рт.ст., реалізація фізичної активності - додатково 4-9 мм рт.ст., обмеження вживання алкоголю - також 2-4 мм рт.ст.

Подальша модифікація лікування АГ у рекомендаціях JNC-V (1993) пов'язана з включенням $\alpha$-адреноблокаторів; доведенням необхідності лікування АГ у літніх осіб та ізольованої систолічної АГ; впровадженням комбінованої антигіпертензивної терапії; створюється нова градація рівнів АТ - відлік стадій АГ вперше почали з показників 140/90 мм рт.ст.

Згідно з JNC-VI (1997) визначені критерії оцінки ризику пацієнтів з АГ залежно АТ і факторів ризику, зворотного розвитку органних уражень; диференційоване призначення антигіпертензивних засобів відповідно до клінічної ситуації: при неускладненій АГ призначаються діуретики i/або $\beta$-АБ, при цукровому діабеті 1-го типу 3 нефропатією - іАПФ, при серцевій недостатності (CH) - iАПФ i/або діуретики, після інфаркту міокарда $з$ дисфункцією ЛШ - іАПФ і/або $\beta$-АБ, у літніх осіб - діуретики i/або дигідропіридинові антагоністи кальцію тривалої дії.

У рекомендаціях JNC VII (2003) уведено термін «передгіпертонія» для позначення осіб із САТ у діапазоні 120-139 мм рт.ст. і ДАТ 80-89 мм рт.ст., що пов'язане з роллю факторів ризику та метою зосередити увагу на сегменті населення, який знаходиться на більш високому ризику серцево-судинних захворювань, приділена увага затвердженню здорового способу життя для досягнення мети, у тому числі в пацієнтів із діабетом або хронічними захворюваннями нирок. Рішення про застосування антигіпертензивних препаратів має бути засноване на глобальному ризику серцево-судинних подій, а не на конкретних рівнях АТ у спокої [12].

Алгоритм лікування АГ наприкінці ХX сторіччя включав наступні групи препаратів:

1) діуретики (гідрохлоротіазид, спіронолактон, індапамід, фуросемід, торасемід, еплеренон, ксипогамма, іноді комбіновані - модуретик);
2) $\beta$-АБ (пропранолол, метопролол, атенолол, бісопролол, бетаксолол, небіволол);

3) антагоністи кальцію (ніфедипін-ретард, дилтіазем, верапаміл, амлодипін, лерканідипін);

4) іАПФ (каптоприл, еналаприл, лізиноприл, раміприл, моексиприл, квінаприл, периндоприл, трандолаприл, фозиноприл, зофеноприл);

5) антагоністи $\mathrm{AT}_{1}$-рецепторів до ангіотензину (лозартан, ірбесартан, вальсартан, кандесартан, телмісартан, епросартан);

6) $\alpha_{1}$-адреноблокатори (празозин, доксазозин);

7) $\alpha_{1}$-адреноблокатори / блокатори серотинінових рецепторів (урапідил);

8) $\alpha+\beta$-адреноблокатори (карведилол);

9) центральні $\alpha_{2}$-агоністи (резерпін (адельфан), метилдопа, клонідин, моксонідин);

10) агоністи імідазолінових $\left(\mathrm{I}_{1}\right)$ рецепторів (моксонідин).

Терапія АГ дозволяє контролювати багатогранність та мозаїчність ії виникнення, а отже, використовувати впливи на зменшення затримки солі і води (діуретики), активовану ренінангіотензин-альдостеронову систему та процеси ремоделювання (інгібітори АПФ, сартани, антагоністи альдостерону, $\beta$-АБ), зменшення поверхневого стресу та роботи серця ( $\beta$-АБ), впливу процесів запалення (статини, антагоністи альдостерону, ацетилсаліцилова кислота) та метаболічного синдрому (агоністи $\mathrm{I}_{1}$-імідазолінових рецепторів), перебігу в умовах аденоми і вагітності, за ролі ліпідної ланки (статини) та тромбоцитарної агрегації (ацетилсаліцилова кислота) тощо (рис. 2).

У той же час раціональні комбінації лікування АГ обмежуються 6-4 класами антигіпертензивних препаратів, як представлено на рисунку 3 .

Найбільш чітко регулює комбінації лікування АГ Постанова № 340 «Про реалізацію пілотного проекту щодо запровадження державного регулювання цін на лікарські засоби для лікування осіб із гіпертонічною хворобою» 3 використанням механізму визначення порівняльних (референтних) цін, вмотивованою реімбурсацією (reimbursement - виплата компенсацій) та представленими на рисунку 4 препаратами. Як зазначає у своїй статті колектив авторів під керівництвом професора Ю.М.Сиренка [4], безкоштовна видача ліків $\epsilon$ найбільш ефективним заходом, незважаючи на те, що система страхової компенсації в країнах Заходу (reimbersment) і так робить придбання необхідних прописаних лікарем препаратів практично безкоштовним.

Таким чином, питання діагностики і лікування АГ залишаються в зоні щільної уваги науковців і клініцистів, організаторів охорони здоров'я в Україні і світі, а проблема АГ визначається не тільки 17 травня - у Всесвітній день боротьби 3 гіпертонією, заснований Всесвітньою лігою боротьби з гіпертонією за підтримки ВООЗ (проводиться з 2005 р.).

\section{Література}

1. Богатирьова Р.В. Артеріальна гіпертензія: державна стратегія профілактики, лікування i упередження 
ускладнень / Р.В. Богатирьова // 2012. - Режим доступу: www.moz.gov.ua/docfiles/AG-10.05.12 .ppt

2. Державна служба статистики // 2012. - Режим доступу: http://www.ukrstat.gov.ua/

3. Коваленко В.М. Національна стратегія боротьби 3 артеріальної гіпертензії в Україні: соціальні та медичні аспекти / В.М. Коваленко // 2012. - Режим доступу: http://www.apteka.ua/wp-content/uploads/2012/05/7-\% D0\%BA \%D0\%BE $\%$ D0\%B2\%D0\%B0\%D0\%BB $\%$ D0 $\%$ B5\%D0\%BD $\%$ D0\%BA $\%$ D0\%BE.pdf

4. Лікарська інерція як важливий чинник на шляху до ефективного лікування АГ / Ю.М. Сіренко, Г.Д. Радченко, О.О. Торбас, І.М. Марцовенко // Артериал. гипертензия. - 2012. - № 1 (21). - Режим доступу: http://www.mif-ua.com/archive/article/26386

5. Наказ МО3 України від 24.05.2012 № 384 «Про затвердження та впровадження медико-технологічних документів зі стандартизації медичної допомоги при артеріальній гіпертензії» // 2012. - Режим доступу: http://moz.gov.ua/ua/print/dn_20120524_384.html

6. Рекомендації Української асоціації кардіологів $з$ профілактики та лікування артеріальної гіпертензії / Робоча група з артеріальної гіпертензії Української асоціації кардіологів // Укр. кардіол. ж. - 2009. - № 1. - Режим доступу: http://www.rql.kiev.ua/cardio j/2009/1/ working group $1 . \mathrm{htm}$

7. 2007 ESH-ESC Guidelines for the management of arterial hypertension: the task force for the management of arterial hypertension of the European Society of Hypertension (ESH) and of the European Society of Cardiology (ESC) /
G. Mansia, G. De Backer, A. Dominiczak [et al.] // J. Hypertens. - 2007. - Vol. 25, № 6. P. 1105-1187.

8. Effects of dietary approaches to stop hypertension (DASH)-style diet on fatal or nonfatal cardiovascular diseases-incidence: a systematic review and meta-analysis on observational prospective studies / A. SalehiAbargouei, Z. Maghsoudi, F. Shirani, L. Azadbakht // Nutrition. - 2013. - Vol. 29, № 4. - P. 611-618.

9. Heart disease and stroke statistics--2012 update: a report from the American Heart Association / V.L. Roger, A.S. Go, D.M. Lloyd-Jones [et al.] // Circulation. - 2012. - Vol. 125, № 1. - P. e2-e220.]. - Available from: http:// www.mc.uky.edu/cvrc/PDF\%20documents/e2.full.pdf

10. Karnath B. Sources of error in blood pressure measurement / B. Karnath // Hosp. Physician. - 2002. Vol. 38, № 3. - P. 33-37]. - Available from: http:// www.turner-white.com/pdf/hp_mar02 error.pdf

11. The Effect of Sodium Restricted Diet on Plasma Visfatin Levels in Hypertensive Patients with Visceral Obesity / S. Rotkegel, J. Chudek, U. Spiechowicz-Zaton [et al.] // Kidney Blood Press Res. - 2013. - Vol. 37, № 2-3. P. 124-131.

12. The Seventh Report of the Joint National Committee on Prevention, Detection, Evaluation, and Treatment of High Blood Pressure - Complete Report / A.V. Chobanian and National High Blood Pressure Education Program Coordinating Committee // 2004. - Available from: http:// www.nhlbi.nih.gov/guidelines/hypertension/jnc7full.pdf

\section{АРТЕРИАЛЬНАЯ ГИПЕРТЕНЗИЯ - ПРОБЛЕМА СОВРЕМЕННОСТИ}

\section{T.Н. Бойчук, В.К. Тащук}

Резюме. Проблема лечения артериальной гипертензии, учитывая ожидаемое количество в 2025 г. в 1,5 млрд человек с повышенным артериальным давлением, демонстрирует необходимость внедрения как современных методов диагностики, так и самых эффективных подходов к лечению, чем и посвящено внедрение на основе принципов «комплаенса» и «эдгиренса» механизмов реимбурсации.

Ключевые слова: артериальная гипертензия, артериальное давление, лечение, реимбурсация.

\section{ARTERIAL HYPERTENSION - THE PROBLEM OF THE PRESENT}

\section{T.M. Boychuk, V.K. Tashchuk}

Abstract. The problem of treating arterial hypertension, taking into account an expected number of 1.5 milliards persons with an elevation of the blood pressure in 2025, demonstrates a need of introducing both modern methods of diagnostics and the most effective approaches to a treatment. The introduction on the basis of the principles of "compliance" and "adherence" of the mechanisms of reimbursement is dedicated to these approaches.

Key words: arterial hypertension, blood pressure, treatment, reimbursement.

Bukovinian State Medical University (Chernivtsi)

Рецензент - д. мед. н. Т.О. Ілащук

Buk. Med. Herald. - 2013. - Vol. 17, № 2 (66). - P. 3-8

Надійшла до редакції 29.04.2013 року

(C) Т.М. Бойчук, В.К. Тащук, 2013 